Webster's definition of true' eloquence: “It's in the man, in the occasion, and in the subject." His printed papers are worthy of study by young men. May God raise up more defenders not only of government, but of general truth.

It would be improper, in a periodical of this sort and space, to speak of his family, a precious wife and three children, dear to him as the apple of his eye. Nor can the writer forget, when leaving their hospitable mansion, how a can was offered him, and he has it now to use, when sickness and other cause will allow its contents to be opened to guests.

Mr. Wilson no longer practices in any but the higher oourts of the State and of the United States. Of his merits as a special pleader, the writer cannot speak from observation, but his general repute is well known. Still comparatively young, he is destined to rise in the world of statesmen.

\title{
REMINISCENCES OF DAVENPORT.
}

In 1840 , the editor of this periodical tarried a few weeks in Davenport, and, with Mr. Strong Burnell, visited Antoine Le Claire, at his home, then the old "Council House." The city was very small. An eighty acre lot could then have been bought very cheap. The pecuniary crash of $1837 \mathrm{had}$ then reached Iowa. No money, no credit, no hope of business prevailed. Mr. Le Claire was then building his first hotel, and that almost swamped his credit, although afterwards business revived and the place grew. There was not probably more than five or six hundred actual settlers.

The Indians came prancing down on the prairie, to visit Mr. Le Claire, and rode in a circle in front of his house. They got a barrel of flour and a large kettle., The women, headed by an aged, gray-headed Indian, were bringing sticks and brush from the bluffs above to boil the porridge, which the lub. berly men were making, thus reversing the order of civilization. The Sacs and Foxes were after their annuities-to visit their old haunts and friends, Le Claire and Col. George Davenport, the latter on Rock Island. The men and squaws were paddling their bark canoes across the rapids to see the Colonel.

Now, how changed is everything! A great city stretches over the then prairies and bluffs, where wild men, birds and beasts revelled. Some ineidents of that early visit may be added. A young man, by the name of Gates, on a Wednesday was seen building a skiff. He and others attached a mast and sails to the small craft. On Sunday they went down to launch and sail their boat. The wind was strong and the waves ran high. A negro waiter at the hotel where Gates boarded, ran down to the brink of the river and entreated him and those with him to not venture into the current, as they would certainly be drowned. They persisted, three of them. No sooner than they had reached the boiling current the boat overset, and, by the action of the wind and current, the boat continued to go over and over. Gates, being a good swimmer, let go of the boat to swim ashore. But he soon sank and never rose nor was heard of more. The writer of this article was called upon to improve the sad event on Sabbath evening. He 
could not say, "the better day, the better deed;" and that his distant friends would rather have had him die in that way on any other day of the week. Sad sight, a young man sinking into a watery grave.

The writer, also, "paddled his own canoe" over the Mississippi-or rather a borrowed one-visited Blackhawk's eave, at the foot of the Island. It took just twenty minutes by the watch, to return from Rock Island shore, then called Stevenson.

With Mr. Strong Burnell, also, he visited Mr. LeClaire and solicited him to give a lot for a Congregational church, which he afterwards did. He said very pleasantly and smilingly, "I have given the Catholics a lot, and, I sup. pose, I must treat them all alike." He was a very generous man, and often boasted that he was the first white man that ever came over the Mississippi. Half Indian and half French by descent, he was more tawny than white.

\section{SKETCH OF ANTOINE LE CLAIRE.}

\section{From "Davenport Past and Present."}

Antorne Le Clarre was born December 15, 1797, at St. Juseph, Michigan, His father was a Canadian Frenchman, his mother the grand daughter of a Pottawottamie chief. At this time the territory of the Northwest, out of which half a dozen mighty States have been formed, was peopled almost solely by the Red man, with here and there one of a different race, fearless enough to brave the perils of frontier life, among the dusky denizens of the wilderness; the father of Antoine Le Claire was one of these.

In 1808 , he established a trading post at Milwaukee, Wisconsin, exchanging manufactured articles for various kinds of furs. In 1809, he engaged more extensively in the business, in connection with John Kinsey, at Chicago, (Fort Dearhorn then) Illinois. In 1812, though surrounded with Indian tribes with whom he was trading, and who, through the influence of British emissaries, were generally hostile to the United States, Mr. Le Claire espoused the American cause, engaged actively in the service-was in the contest at Peoria, where, with others, he was taken prisoner. The prisoners were confined at Alton, Illinois, but were released during the same year.

About this period, at the solicitation of Gov. Clarke, of Missouri, Antoine Le Claire entered the Government service, and was placed at school, that he might acquire a proper knowledge of the English language,. In 1818, he acted as interpreter under Capt. Davenport, at Fort Armstrong; and the same year returned to Peoria, where, in 1820 , he married the grand-daughter of the Sac Chief, Acoqua, (the Kettle.) The same year he was sent to Arkansas, to watch the movements of the Indians in that locality. He was returned to Fort Armstrong in 1827 , and was present as interpreter in 1832 , when the treaty was made by which the United States purchased of the Sac and Fox tribes the territory west of the Mississippi river.

In consequence of cholera among the soldiers at Fort Armstrong, the treaty, which would otherwise have been held in the Fort, was transferred to the Iowa shore opposite. Here the great chief of the Sacs, Keokuk, made a reserve of a section of land, which be donated to Mr. Le Claire's wife, requir- 
Copyright of Annals of Iowa is the property of State of Iowa, by \& through the State Historical Society of Iowa and its content may not be copied or emailed to multiple sites or posted to a listserv without the copyright holder's express written permission. However, users may print, download, or email articles for individual use. 